Research article

Open Access

\title{
Ameliorative Effects of a Polyphenolic Fraction of Cinnamomum zeylanicum L. Bark in Animal Models of Inflammation and Arthritis
}

\author{
Badal Rathi ${ }^{1}$, Subhash BodhankaR ${ }^{*}{ }^{1}$, V. Mohan $^{2}$, Prasad ThaKURdeSal ${ }^{2}$ \\ ${ }^{1}$ Poona College of Pharmacy, Bharati Vidyapeeth Deemed University, Erandwane, Pune- 411 038, India. \\ ${ }^{2}$ Indus Biotech Private Limited, 1, Rahul Residency, Plot Nos. 6 \& 7, Off Salunke Vihar Road, Kondhwa, \\ Pune-411 048, Maharashtra, India. \\ * Corresponding author. E-mail: sbodhindus@gmail.com (S. Bodhankar)
}

Sci Pharm. 2013; 81: 567-589

doi:10.3797/scipharm.1301-16

Published: $\quad$ February $25^{\text {th }} 2013$

Received: January $19^{\text {th }} 2013$

Accepted: $\quad$ February $25^{\text {th }} 2013$

This article is available from: http://dx.doi.org/10.3797/scipharm.1301-16

(c) Rathi et al.; licensee Österreichische Apotheker-Verlagsgesellschaft m. b. H., Vienna, Austria.

This is an Open Access article distributed under the terms of the Creative Commons Attribution License (http://creativecommons.org/licenses/by/3.0/), which permits unrestricted use, distribution, and reproduction in any medium, provided the original work is properly cited.

\begin{abstract}
Cinnamon bark (Cinnamomum zeylanicum Syn C. verum, family: Lauraceae) is one of the oldest traditional medicines for inflammatory- and pain-related disorders. The objective of the present study was to evaluate the efficacy of the polyphenol fraction from Cinnamomum zeylanicum bark (CPP) in animal models of inflammation and rheumatoid arthritis. Dose-response studies of CPP (50, 100, and $200 \mathrm{mg} / \mathrm{kg}$ ) used in a separate set of in vivo experiments were conducted in acute (carrageenan-induced rat paw edema), subacute (cotton pellet-induced granuloma), and sub-chronic (AIA, adjuvant-induced established polyarthrtis) models of inflammation in rats and the acetic acid-induced writhing model of pain in mice. Effects of CPP on cytokine (IL-2, IL-4, and IFNy) release from Concanavalin (ConA)-stimulated lymphocytes were also evaluated in vitro. CPP showed a strong and dose-dependent reduction in paw volume, weight loss reversal effects against carrageenan-induced paw edema, and cotton pellet-induced granuloma models in rats. CPP (200 mg/kg p.o. for 10 days) showed a significant reduction in elevated serum TNF- $\alpha$ concentration without causing gastric ulcerogenicity in the AIA model in rats. CPP also demonstrated mild analgesic effects during acute treatment as evidenced by the reduction in the writhing and paw withdrawal threshold of the inflamed rat paw during the acetic acid-induced writhing model and Randall-Selitto test. CPP was found to inhibit cytokine (IL-2, IL-4, and IFNY) release from ConA-stimulated lymphocytes in vitro. In conclusion, CPP demonstrated prominent action in
\end{abstract}


animal models of inflammation and arthritis and therefore can be considered as a potential anti-rheumatic agent with disease-modifying action.

\section{Keywords}

\section{Cinnamon bark • Antiinflammatory $\bullet$ Rheumatoid arthritis}

\section{Introduction}

Rheumatoid arthritis (RA) is a chronic, inflammatory autoimmune disease affecting freely movable joints, such as hand, knee, and shoulder joints. The symptoms of active RA include pain, swelling, morning stiffness, warmth, redness, and limited functioning of the joints. The systemic ramifications of the disease, apart from morbidity and mortality, include cardiopathy, nephropathy, vasculopathy, pulmonary, and cutaneous disorders [1]. Although the cause of rheumatoid arthritis is unknown, autoimmunity plays a pivotal role in both its chronicity and progression, and RA is considered to be a systemic autoimmune disease. Existing treatment therapies for RA usually focus on anti-inflammatory activity. They help to manage the process of inflammation and thus may also help in the repair process. Medications like nonsteroidal anti-inflammatory drugs (NSAIDs), corticosteroids, and analgesics are used to suppress symptoms, while disease-modifying anti-rheumatic drugs (DMARDs) and biological response modifiers are often required to inhibit or halt the underlying immune process and prevent long-term damage. Therefore, the search for safer drugs for the management of rheumatoid arthritis for chronic use is still on.

Cinnamon bark (Cinnamomum zeylanicum Syn C. verum, family: Lauraceae) is one of the oldest herbal medicines mentioned in many traditional texts for inflammation [2] and pain related to disorders such as enteralgia (acute intestinal pain), bronchitis, and rheumatism [3]. It is native to Sri Lanka Mayanmar (Burma) and the southern coastal strip of India. In Chinese traditional medicine, cinnamon is indicated as an analgesic and antipyretic against colds, fever, headache, myalgia (mascular pain), arthralgia (arthritic pain), and amenorrhea (failure of menstruation). In Indian traditional literature including Ayurveda and 'Materia Medica of India and their Therapeutics', many other valuable actions are attributed to cinnamon bark and oil [4].

Many scientific pharmacological investigations have also reported on the anti-inflammatory potential of bark of many species of cinnamon $[3,5,6]$. The anti-inflammatory action of the Japanese species Cinnamomum seiboldii [7] and Cinnamomi cortex [8] has been attributed to a series of tannins. An herbal ophthalmic medicament called Ophthacare, which contains $0.5 \%$ cinnamon, was tested for its anti-inflammatory activity on ocular inflammation in rabbits and found to be effective [9]. The antinoiceptive activity (analgesic) [10] and antipyretic (fever-reducing) activity of cinnamon (C. verum) bark [7] were also reported.

Another important activity is the immunomodulatory effects exerted by cinnamon. An interesting fact about cinnamon is that it can act both as an immunostimulant and an immunosuppressant depending on the species and dose [11]. In vitro inhibitory activity against the complement formation has been documented for cinnamon cortex and cinnamon oil [11]. The extract of cinnamon bark is reported to have anticomplementary activity [12] and immunosuppressive activity $[13,14]$. Cinnamon bark's potential for 
relieving inflammation and pain, and enhancing the immune system, makes it a good candidate as an antiarthritic agent.

Furthermore, cinnamon polyphenol extract (CPE) from the cinnamon bark of various varieties has shown potential for the management of certain human health conditions. Procyanidins or condensed tannins are flavonoid oligomers whose building blocks are $(+)$-catechin and (-)-epicatechin. They are oligomeric end products of the flavonoid biosynthetic pathway and are now identified and recognised for their favourable effects in human beings. Based on the linkage between the successive monomeric units, procyanidins are classified as Types A, B, or C procyanidine polyphenols.

Recently, the immunomodulatory effect of the water extract of cinnamon on anti-CD3induced cytokine responses and p38, JNK, ERK1/2, and STAT4 activation [13] has been shown. CPE is known to affect immune responses by regulating anti- and proinflammatory and GLUT gene expression as seen in an in vitro study on mouse RAW264.7 macrophages [15]. However, a functional outcome of these effects in an animal model of rheumatoid arthritis has not been investigated.

The objective of the present work is aimed to investigate the functional effects and probable mechanism of action of polyphenols isolated from Cinnamomum zeylanicum bark (CPP) in an animal model of acute inflammation and established rheumatoid arthritis in rats. CPP was tested against animal models of acute (carrageenan-induced), subacute (cotton pallet granuloma), and chronic (Freund's complete adjuvant, FCA, induced established poly arthritis) models of inflammation. CPP was also tested for its potential analgesic activity against inflammaotoy pain and ulcerogenicity.

\section{Results and Discussion}

\section{Characterization of CPP}

As an initial chemical characterization of the CPP, total phenolic content was determined and found to be $860 \mathrm{mg}$ of gallic acid equivalant (GAE) per g. As an additional characterization, an HPLC study was performed. The HPLC spectra showed the presence of polyphenols with a similar absorption pattern to procyanidines with two bands of maximum absorption around a retention time of 30 to $38 \mathrm{~min}$, which matches with the trimer and tetramer of proanthocyanidins polyphenols as reported earlier [16] and suggests the predominance of polyphenolic compounds in CPP (Fig. 1).

\section{Effect of CPP against carrageenan induced rat paw edema in rats}

As shown in Table 1, subplanter administration of carrageenan caused an increase in the paw volumes of rats (an increase of $2.63 \mathrm{ml}$ within 3 hours) which indicates edema formation (inflammation) in rat paws. Acute oral administration of celecoxib $(10 \mathrm{mg} / \mathrm{kg})$ prevented the edema formation significantly $(P<0.001)$ and showed an increase in the paw volume by $1.42 \mathrm{ml}$ (45.79\% inhibition) at 3 hours. Acute oral administration of CPP showed dose-dependent inhibition of carrageenan-induced edema $(21.83,33.19$, and $39.97 \%$ inhibition) at 50, 100, and $200 \mathrm{mg} / \mathrm{kg}$, p.o., respectively, at $3 \mathrm{~h}$. 


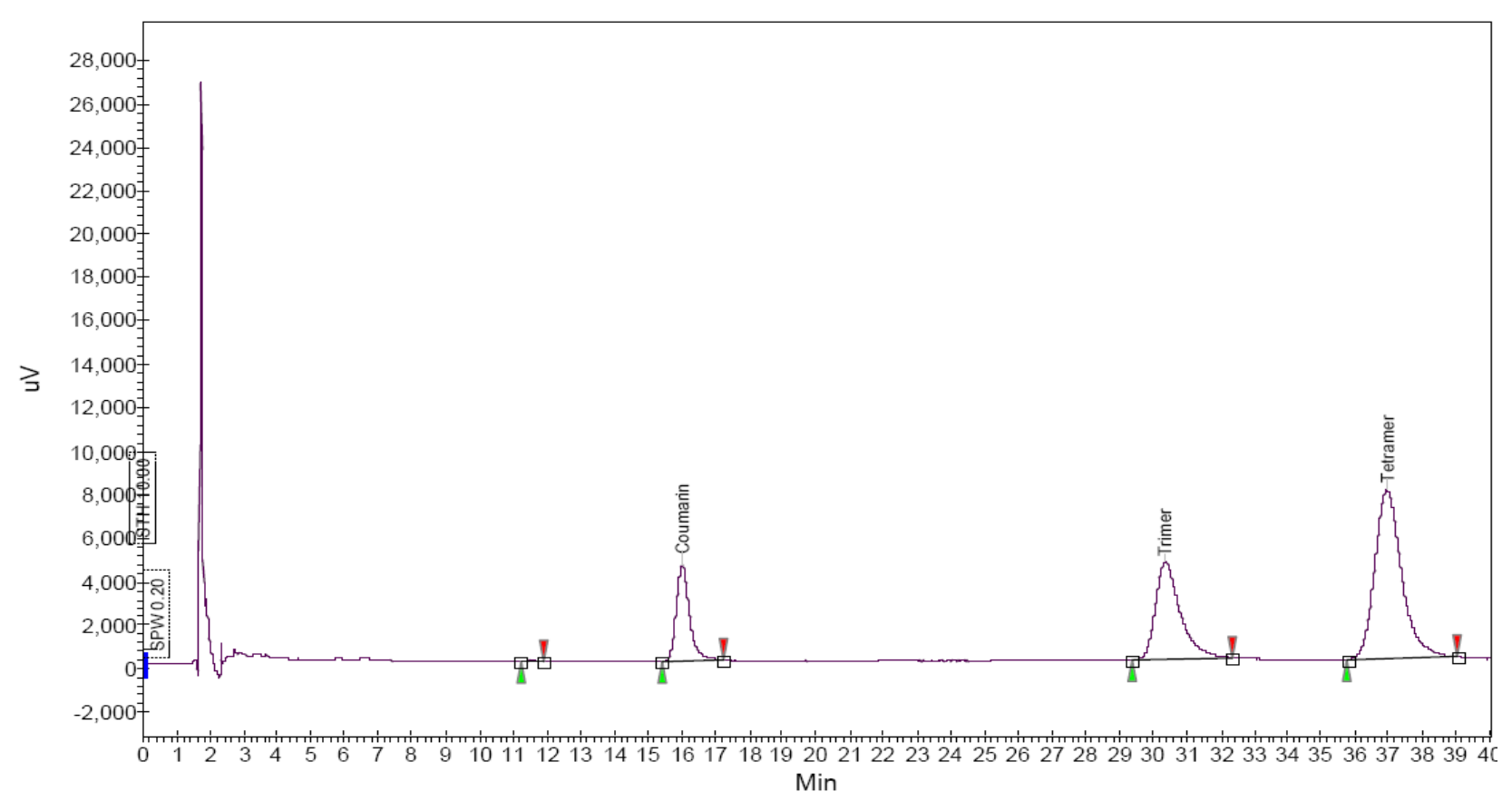

Fig. 1. HPLC spectra of CPP at $280 \mathrm{~nm}$.

None of the treatments showed significant inhibition of paw edema at $1 \mathrm{~h}$ after carrageenan administration. However, at $2 \mathrm{~h}$, CPP showed significant inhibition of paw edema at a dose of $200 \mathrm{mg} / \mathrm{kg}$ (37.27\% inhibition).

\section{Effect of CPP on pain threshold during the Randall-Selitto test in rats}

The pain threshold was measured mechanically at $3 \mathrm{~h}$ and pressure levels at which rats elicited the response of struggling, squealing, or vocalization were taken as the pain threshold. Vehicle control rats showed a PWT of $66 \mathrm{~g}$. Celecoxib (10 mg/kg, p.o) increased paw withdrawal latency (PWT) by 36.4\%, whereas CPP (100 and $200 \mathrm{mg} / \mathrm{kg}$, p.o.) increased PWT by 16.66 and 20.73\%, respectively. However, CPP (50 mg/kg, p.o.) did not increase PWT significantly as compared with the vehicle-treated rats. Thus, CPP demonstrated mild analgesic activity on the pain responses elicited by the mechanical stimulus.

\section{Effect of CPP in cotton pellet granuloma in rats}

Implantation of cotton pellets produced granuloma formation, which was measured by weighing the dried pellet after 7 days post-implantation. In the vehicle-treated rats, the mean cotton pellet weight was increased by $123 \%$ (from $20 \mathrm{~g}$ to $44.67 \mathrm{~g}$ ). After seven days of treatment with celecoxib (10 mg/kg/day) and CPP $(50,100$, and $200 \mathrm{mg} / \mathrm{kg} / \mathrm{day})$, the dry weights of the cotton pellet granuloma were found to reduce by $43.51 \%, 27.31 \%, 34.40 \%$, and $38.92 \%$, respectively, which was significant as compared with the weights of granuloma tissues in the vehicle control rats (Table 2). 
Tab. 1. Effect of CPP against carrageenan-induced rat paw edema in rats

\begin{tabular}{|c|c|c|c|c|c|}
\hline \multirow{2}{*}{$\begin{array}{l}\text { Treatment } \\
\text { (dose, } \\
\text { mg/kg, } \\
\text { route) }\end{array}$} & \multicolumn{4}{|c|}{ Mean Paw Volume (mL.) \pm SEM } & \multirow{2}{*}{$\begin{array}{c}\text { PWT in } \\
\text { Randall-Selitto } \\
\text { assay at } 3 \mathrm{~h} \\
\text { (g } \pm \text { SEM) } \\
\text { (\% increase) }\end{array}$} \\
\hline & $\mathbf{O h}$ & $1 \mathrm{~h}$ & $2 \mathrm{~h}$ & $3 \mathbf{h}$ & \\
\hline $\begin{array}{l}\text { Vehicle } \\
\text { control }\end{array}$ & $\begin{array}{c}2.60 \\
\pm 0.07\end{array}$ & $\begin{array}{c}3.65 \\
\pm 0.21\end{array}$ & $\begin{array}{c}4.81 \\
\pm 0.21\end{array}$ & $\begin{array}{c}5.23 \\
\pm 0.13\end{array}$ & $\begin{array}{l}66.00 \\
\pm 7.8\end{array}$ \\
\hline $\begin{array}{l}\text { Celecoxib } \\
(10, \text { p.o.) }\end{array}$ & $\begin{array}{r}2.75 \\
\pm 0.07\end{array}$ & $\begin{array}{c}3.55 \\
\pm 0.15 \\
(23.44)\end{array}$ & $\begin{array}{c}4.43 \\
\pm 0.17 \\
(24.04)\end{array}$ & $\begin{array}{c}4.18^{C} \\
\pm 0.29 \\
(45.79)\end{array}$ & $\begin{array}{c}90.00^{\mathrm{C}} \\
\pm 7.9 \\
(36.4)\end{array}$ \\
\hline $\begin{array}{l}\text { CPP } \\
(50, \text { p.o. })\end{array}$ & $\begin{array}{r}2.79 \\
\pm 0.07\end{array}$ & $\begin{array}{c}3.70 \\
\pm 0.19 \\
(12.76)\end{array}$ & $\begin{array}{c}4.72 \\
\pm 0.17 \\
(12.81)\end{array}$ & $\begin{array}{c}4.84 \\
\pm 0.37 \\
(21.83)\end{array}$ & $\begin{array}{c}74.3 \\
\pm 4.08 \\
(12.63)\end{array}$ \\
\hline $\begin{array}{l}\text { CPP } \\
(100, \text { p.o. })\end{array}$ & $\begin{array}{c}2.72 \\
\pm 0.10\end{array}$ & $\begin{array}{c}3.24 \\
\pm 0.13 \\
(12.28)\end{array}$ & $\begin{array}{c}4.28 \\
\pm 0.05 \\
(29.54)\end{array}$ & $\begin{array}{l}4.48^{b} \\
\pm 0.09 \\
(33.19)\end{array}$ & $\begin{array}{l}75.00^{a} \\
\pm 4.14 \\
(16.66)\end{array}$ \\
\hline $\begin{array}{l}\text { CPP } \\
(200, \text { p.o. })\end{array}$ & $\begin{array}{c}2.47 \\
\pm 0.10\end{array}$ & $\begin{array}{c}3.30 \\
\pm 0.10 \\
(21.05)\end{array}$ & $\begin{array}{l}3.91^{\mathrm{c}} \\
\pm 0.14 \\
(37.27)\end{array}$ & $\begin{array}{c}4.05^{c} \\
\pm 0.03 \\
(39.97)\end{array}$ & $\begin{array}{c}81.0^{c} \\
\pm 0.97 \\
(20.73)\end{array}$ \\
\hline ficanc & sent & $\begin{array}{l}\text { Mea } \\
\text { ures } \\
{ }^{a} \mathrm{P}\end{array}$ & $\begin{array}{l}\text { volur } \\
\text { A foll }\end{array}$ & nl.) $\pm S$ & $\begin{array}{l}\text { ind was analyzed } \\
\text { oni posttests. } \\
\text { as compared to }\end{array}$ \\
\hline
\end{tabular}

Tab. 2. Effect of CPP in cotton pellet granuloma- and acetic acid-induced writhing model in rats

\begin{tabular}{|c|c|c|}
\hline Treatment & $\begin{array}{c}\text { Mean weight of cotton pellet } \\
\text { granuloma } \pm \text { S.E.M. } \\
\text { (\% Inhibition) }\end{array}$ & $\begin{array}{l}\text { Mean number of writhes } \\
\text { against acetic acid } \\
\text { (\% analgesia) }\end{array}$ \\
\hline Vehicle control & $44.67 \pm 1.60$ & $29.17 \pm 0.48$ \\
\hline Celecoxib (10, p.o.) & $\begin{array}{c}25.23 \pm 0.47^{c} \\
(43.51)\end{array}$ & $\begin{array}{c}13.83 \pm 0.60^{c} \\
(52.59)\end{array}$ \\
\hline CPP $(50$, p.o. $)$ & $\begin{array}{c}32.47 \pm 0.49^{c} \\
(27.31)\end{array}$ & $\begin{array}{c}25.33 \pm 1.05 \\
(13.16)\end{array}$ \\
\hline CPP $(100$, p.o. $)$ & $\begin{array}{c}29.30 \pm 0.81^{c} \\
(34.40)\end{array}$ & $\begin{array}{c}23.83 \pm 1.30 \\
(18.31)\end{array}$ \\
\hline CPP (200, p.o.) & $\begin{array}{c}27.28 \pm 1.25^{\mathrm{c}} \\
(38.92)\end{array}$ & $\begin{array}{c}22.00 \pm 1.53^{\mathrm{a}} \\
(24.58)\end{array}$ \\
\hline
\end{tabular}


Tab. 3. Effect of CPP on Body weight, Paw edema, and serum TNFa levels at baseline, Day-12 and Day-21 post-sensitization in FCA-induced established polyarthritis (AIA model)

\begin{tabular}{|c|c|c|c|c|c|c|}
\hline \multirow[t]{2}{*}{ Parameter } & \multirow[t]{2}{*}{ Day } & \multicolumn{5}{|c|}{ Mean Parameter value (dose in $\mathrm{mg} / \mathrm{kg}$ ) } \\
\hline & & AIA & Celecoxib (10) & CPP (50) & CPP (100) & CPP (200) \\
\hline \multirow{6}{*}{$\begin{array}{l}\text { Body } \\
\text { weight (g) }\end{array}$} & \multirow{2}{*}{0} & 171.00 & 170.17 & 170.17 & 173.33 & 170.33 \\
\hline & & \pm 1.67 & \pm 1.99 & \pm 1.99 & \pm 3.02 & \pm 4.29 \\
\hline & \multirow{2}{*}{12} & $141.00^{\mathrm{a}}$ & $159.17^{\mathrm{a}}$ & $159.17^{\mathrm{a}}$ & $162.50^{\mathrm{a}}$ & $158.00^{\mathrm{a}}$ \\
\hline & & \pm 2.16 & \pm 2.75 & \pm 2.75 & \pm 1.84 & \pm 2.19 \\
\hline & \multirow{2}{*}{21} & 136.33 & $188.33^{b}$ & $188.33^{b}$ & $195.17^{\mathrm{b}}$ & $197.67^{\mathrm{b}}$ \\
\hline & & \pm 2.40 & \pm 3.00 & \pm 3.00 & \pm 1.60 & \pm 3.38 \\
\hline \multirow{6}{*}{$\begin{array}{l}\text { Paw Volume } \\
(\mathrm{ml})- \\
\text { Injected - Left }\end{array}$} & \multirow[b]{2}{*}{ 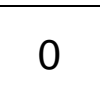 } & 2.67 & 2.47 & 2.56 & 2.13 & 2.47 \\
\hline & & \pm 0.14 & \pm 0.17 & \pm 0.13 & \pm 0.08 & \pm 0.15 \\
\hline & \multirow{2}{*}{12} & $5.75^{\mathrm{a}}$ & $5.28^{a}$ & $5.59^{\mathrm{a}}$ & $5.18^{\mathrm{a}}$ & $5.25^{a}$ \\
\hline & & \pm 0.09 & \pm 0.16 & \pm 0.16 & \pm 0.18 & \pm 0.85 \\
\hline & \multirow[b]{2}{*}{1} & 5.65 & $3.18^{b}$ & $4.24^{b}$ & $3.31^{b}$ & $3.40^{\mathrm{b}}$ \\
\hline & & \pm 0.09 & \pm 0.06 & \pm 0.26 & \pm 0.17 & \pm 0.62 \\
\hline \multirow{6}{*}{$\begin{array}{l}\text { Paw Volume } \\
(\mathrm{ml})- \\
\text { Contralateral - } \\
\text { Right }\end{array}$} & \multirow{2}{*}{0} & 2.16 & 1.99 & 1.96 & 2.18 & 2.03 \\
\hline & & \pm 0.15 & \pm 0.13 & \pm 0.14 & \pm 0.03 & \pm 0.41 \\
\hline & \multirow{2}{*}{12} & $3.44^{\mathrm{a}}$ & $3.42^{\mathrm{a}}$ & $3.42^{\mathrm{a}}$ & $3.65^{a}$ & $3.60^{\mathrm{a}}$ \\
\hline & & \pm 0.11 & \pm 0.09 & \pm 0.29 & \pm 0.08 & \pm 0.59 \\
\hline & \multirow{2}{*}{21} & 3.90 & 2.81 & 3.78 & 3.15 & $2.26^{b}$ \\
\hline & & \pm 0.16 & \pm 0.14 & \pm 0.45 & \pm 0.08 & \pm 0.05 \\
\hline \multirow{5}{*}{$\begin{array}{l}\text { TNFa levels } \\
(\mathrm{pg} / \mathrm{ml})\end{array}$} & 0 & $\begin{array}{r}20.05 \\
\pm 0.25\end{array}$ & $\begin{array}{r}28.86 \\
\pm 0.48\end{array}$ & - & - & $\begin{array}{r}33.53 \\
\pm 0.42\end{array}$ \\
\hline & \multirow{2}{*}{12} & $49.63^{a}$ & $47.82^{a}$ & \multirow{2}{*}{-} & \multirow{2}{*}{-} & $47.45^{\mathrm{a}}$ \\
\hline & & \pm 2.53 & \pm 2.94 & & & \pm 2.03 \\
\hline & \multirow[t]{2}{*}{21} & 52.58 & $33.72^{b}$ & \multirow{2}{*}{-} & \multirow{2}{*}{--} & $37.40^{b}$ \\
\hline & & \pm 2.44 & \pm 2.70 & & & \pm 2.83 \\
\hline \multicolumn{7}{|c|}{$\begin{array}{l}\mathrm{n}=6 \text {, Data is represented as Mean parameter value } \pm \text { SEM. The data for each parameter was separately } \\
\text { analyzed by Two-way repeated measures ANOVA followed by Bonferroni posttests. Significance } \\
\text { represented as }{ }^{\mathrm{a}} \mathrm{P}<0.001 \text { as compared with baseline (day-0) values of same treatment group. }{ }^{\mathrm{b}} \mathrm{P}< \\
0.001 \text { as compared to Day-12 values of same treatment group. }\end{array}$} \\
\hline
\end{tabular}

Tab. 4. Effect of CPP on IL2, IL-4, and IFN-y in ConA-stimulated lymphocytes in vitro

\begin{tabular}{lccc}
\hline Treatment & \multicolumn{3}{c}{ Cytokine concentration \pm S.E.M. (pg/ml) } \\
\cline { 2 - 4 } & IL-2 & IL-4 & IFNy \\
\hline Control & $1.94 \pm 0.24$ & $25.02 \pm 1.03$ & $20.41 \pm 0.54$ \\
ConA $(40 \mu \mathrm{l})$ & $589.00 \pm 8.8^{\mathrm{a}}$ & $114.75 \pm 3.89^{\mathrm{a}}$ & $277.74 \pm 7.26^{\mathrm{a}}$ \\
CPP $(100 \mu \mathrm{l}, 0.4 \%)$ & $10.27 \pm 0.26^{\mathrm{b}}$ & $41.22 \pm 1.90^{\mathrm{b}}$ & $21.98 \pm 1.03^{\mathrm{b}}$ \\
\hline Each reading is mean of triplicate readings obtained from ELISA assay. Data was \\
analyzed by Two-way ANOVA followed by Bonferroni posttests. ${ }^{\mathrm{a}} \mathrm{P}<0.001$ as \\
compared with Control' ${ }^{\mathrm{b}} \mathrm{P}<0.001$ as compared with ConA treated group test. \\
\hline
\end{tabular}




\section{Effect of CPP against acetic acid-induced writhing in rats}

The mean number of writhes induced by the intraperitoneal administration of acetic acid $(0.1 \mathrm{ml}, 0.6 \% \mathrm{v} / \mathrm{v})$ was 29.17 in the vehicle control group which confirms the induction of abdominal pain (Table 2). The mean numbers of writhes were significantly reduced in animals pretreated orally with celecoxib (13.83 writhes, $52.59 \%$ reduction) and CPP (22 writhes, $24.58 \%$ reduction). However, CPP did not exhibit a significant reduction in writhing at an acute oral dose of $50 \mathrm{mg} / \mathrm{kg}$ or $100 \mathrm{mg} / \mathrm{kg}$ (Table 2).

\section{Effect of CPP against FCA-induced established polyarthritis (AIA model)}

Effect on Body weight in the AlA model

Immunization of rats with FCA produced a gradual and significant $(P<0.001)$ decrease in the body weight of rats as observed on day-12 of the study in all rats (Table 3 ). The decrease was sustained in adjuvant-induced arthritic rats treated with the vehicle (AIA control). Nine days of daily oral administration (day-12 to day-21) of CPP (50,100, and $200 \mathrm{mg} / \mathrm{kg} / \mathrm{day})$ and celecoxib (10 mg/kg/day) caused a dose-dependent and significant ( $P$ $<0.001$ ) reversal of the FCA-induced body weight decline as seen on day-21.

\section{Effect on paw edema in the AIA model}

The immunization of rats by a subplanter injection of FCA induced a local inflammatory reaction in the injected paw (primary response) and a secondary response in the noninjected (contralateral) paw in 12 days post-immunization (Table 3). The significant increase in paw volumes was observed both in the injected and non-injected (contralateral) paws on day-12 of the study in all rats (Table 3) confirming the induction of arthritis in rats. Oral treatment of CPP (50, 100, and $200 \mathrm{mg} / \mathrm{kg} /$ day) and celcoxib (10 $\mathrm{mg} / \mathrm{kg} /$ day) from day-12 to day-21 (9 days), brought upon a dose-dependent and significant $(P<0.001)$ reduction in the paw volumes in FCA-injected paws (Table 3). On the other hand, contralateral paw volumes were significantly reduced only by CPP (200 $\mathrm{mg} / \mathrm{kg} / \mathrm{day}$ for 9 days) treatment $(P<0.001)$ (Table 3). Celecoxib $(10 \mathrm{mg} / \mathrm{kg})$ and CPP $(50$ and $100 \mathrm{mg} / \mathrm{kg}$ ) did not show a significant reduction in contralateral paw volumes on day21 post-immunization (Table 3 ).

\section{Effect on serum TNFa levels in the AIA model}

Administration of FCA into the sub-plantar region of rats significantly $(P<0.001)$ increased the serum TNF $\alpha$ concentration on day-12 in all the rats (Table 3). The serum TNF- $\alpha$ concentration continued to be at higher levels in the adjuvant-induced arthritis control (AIA) group as seen on day 21 (Table 3). Serum TNF- $\alpha$ concentration was significantly $(P<0.001)$ decreased on day 21 in rats treated with CPP $(200 \mathrm{mg} / \mathrm{kg} /$ day $)$ and celecoxib (10 mg/kg/day) for 9 days as compared to corresponding levels on day-12 (Table 3).

\section{Effect on gastric mucosa in the AIA model}

The gastric mucosal superficial layer of sections of stomach samples of rats removed from normal non-arthritic (Figure 2A) rats was found to be smooth. The mucosal epithelial layer of the stomach sections of FCA-induced arthritic rats after subacute treatment with the vehicle (Figure 2B) and CPP at oral dose of $200 \mathrm{mg} / \mathrm{kg}$ (Figure 2D) were also found to be normal and smooth with mild capillary dilation. However, the superficial layer of the gastric 
mucosa of rats treated with the subacute treatment of celecoxib (10 mg/kg, p.o.) had multiple areas of erosions and hemorrhage (Figure $2 \mathrm{C}$ ).
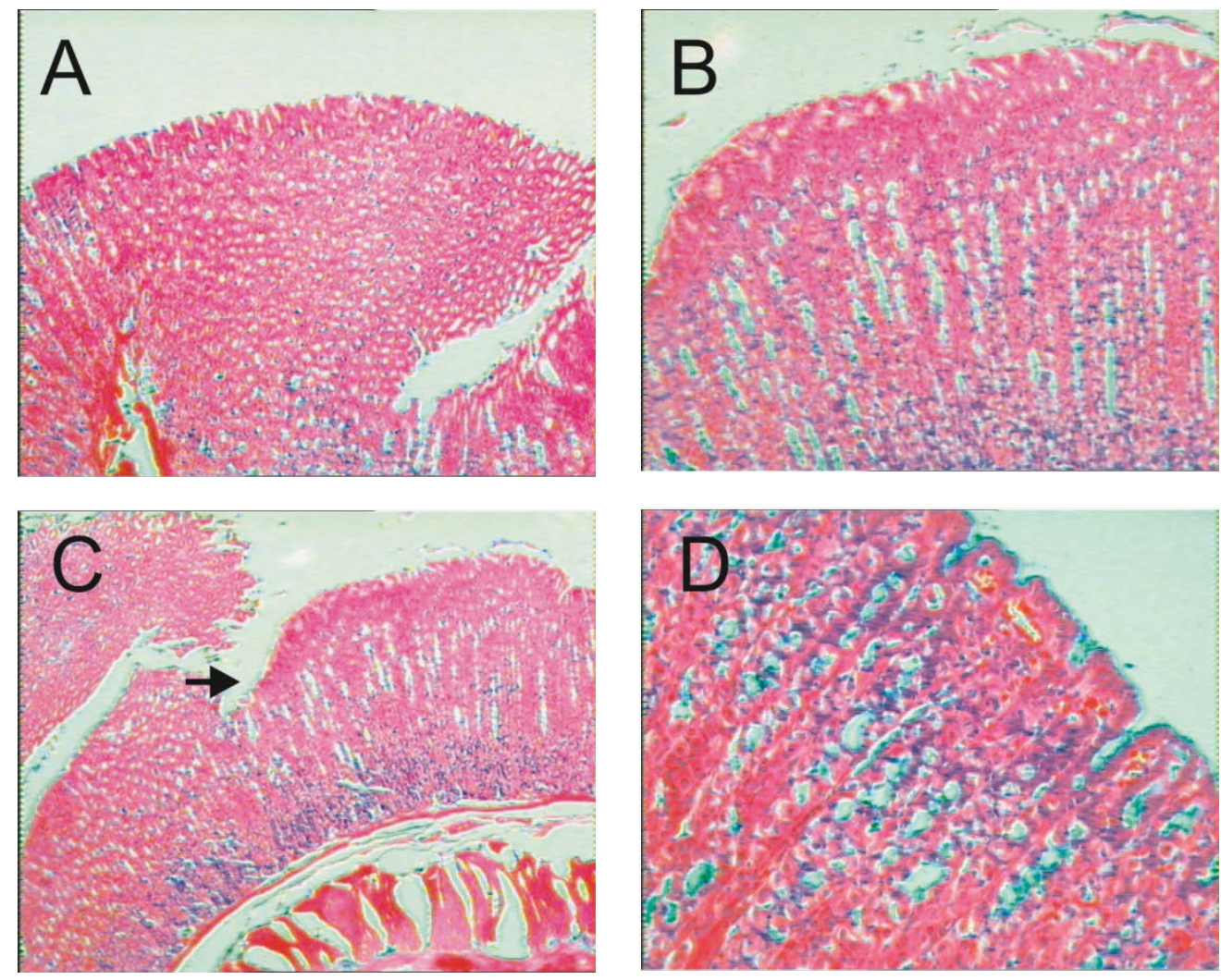

Fig. 2. Photomicrograph of sections of stomach on Day 21 of the study. The figures show sections of stomach of rats with absence of arthritis $(A)$ and FCA-induced arthritis-induced rats with 10-day treatment of vehicle (distilled water) (B), celecoxib (10 mg/kg, p.o.) (C) and CPP (200 mg/kg, p.o.). Arrow indicates erosion with hemorrhage at the superficial part of the mucosa. Stained with hematoxylin and eosin (H\&E) X 200.

\section{Effect of CPP on Concanavalin (Con-A)stimulated lymphocyte culture in vitro}

The levels of IL2, IL4, and IFNy in normal lymphocytes (non-stimulated) were 1.94, 25.02, and $20.41 \mathrm{pg} / \mathrm{ml}$, respectively (Table 4). The ConA-stimulated proliferation of the splenic lymphocyte culture showed a significant $(P<0.001)$ increase in cytokine expression (IL-2, IL-4, and IFNy levels were 589, 114.75, and $277.74 \mathrm{pg} / \mathrm{ml}$, respectively). CPP treatment brought about a significant $(P<0.001)$ reduction in IL-2, IL-4, and IFNy levels (Table 4) of ConA-stimulated lymphocytes and showed IL-2, IL-4, and IFNy levels of 10.27, 41.22, and $21.98 \mathrm{pg} / \mathrm{ml}$ respectively.

\section{Discussion}

Although NSAIDs, DMARDs, and corticosteroids appear to be highly efficient drugs in the treatment of rheumatoid arthritis, they may cause side effects that can range in severity from mild to serious. The major adverse drug reactions (ADRs) associated with NSAIDs are gastrointestinal (ulceration or bleeding) with effects on other systems. During their 
clinical use, gastrointestinal toxicities especially as upper gastrointestinal adverse events such as perforation, ulceration, and bleeding are reported in about $20 \%$ of patients taking long-term NSAIDs which is a major clinical limitation [17]. Besides, some NSAIDs were recently withdrawn from the market because of the risk of heart attacks and stroke, and some other NSAIDs contained a 'Black Box' Warning in the package-inserts, addressing the risk of suffering from heart attacks and/or stroke $[18,19]$. On the other hand, other arthritis therapies such as DMARDs and biological agents had risks of immune suppression and serious infection, respectively, with long-term usage.

Proanthocyanidins (procyanidin, oligomeric proanthocyanidin (OPC), leukocyanidin, leucoanthocyanin, and condensed tannins) are a class of flavanols. The cinnamon polyphenol extract (CPE) is water-soluble and can be standardized to proanthocyanidins [20]. Proanthocyanidins are essentially polymer chains of flavonoids such as catechins [21]. The anti-inflammatory action of many species of cinnamon has been attributed to the polyphenolic component such as tannins [7] and procyanidins [21]. Therefore, we have successfully prepared the standardized polyphenol fraction from the hydroalcoholic extract of Cinnamomum zylanicum bark (labelled as CPP) and evaluated it against animal models of inflammation and arthritis. Total phenolic content (TPC) of CPP was also determined by the well-established Folin-Ciocalteu reagent method [22] and was found to be $860 \mathrm{mg}$ GAE/g in the present study.

The carrageenan-induced rat paw edema is an in vivo test for the evaluation of acute inflammatory activity. The recognition of different mediators for different phases of the carrageenan-induced edema has important implications for interpreting the antiinflammatory effects of the drugs. The development of such edema in the rat paw is a biphasic event. The initial phase of the edema has been attributed to the release of histamine and serotonin which is then maintained during the plateau phase because of kinin-like substances [23]. Further, involvement of histamine and serotonin with other mediators in the pathogenesis of rheumatoid arthritis was also reported by many workers [24-26]. Effectiveness of the test compounds in the first hour after carrageenan injection is indicative of their antihistaminic and/or anti-serotonin action. Second, the accelerating phase of carrageenan edema is attributed to the release of prostaglandins [27].

Our test compound, CPP was not effective in the first hour of treatment but was found to be effective in the third hour at $100 \mathrm{mg} / \mathrm{kg}$ and at higher doses, suggesting prostaglandin inhibition as a possible mechanism of the action effect (Table 1). Tissue granulation is one of the distinctive features of inflammation, which is composed of a marked infiltration of macrophages and neovascularisation. This condition can be induced in rats by subcutaneous implantation of a sterile cotton pellet. The implanted material induces the host's inflammatory response and modulates the release of inflammatory mediators which finally leads to tissue proliferation and granuloma formation [28]. The cotton pellet-induced granuloma is closely related to the formation of antibodies and the resultant inflammation involves the infiltration of macrophages and neutrophils, and the proliferation of fibroblasts. The multiplications of small blood vessels as well as the proliferation of fibroblasts are the characteristic features at the repair phase of inflammation [29]. Such proliferating cells penetrate the exudates, producing a highly vascularized reddened mass known as granulation tissue [30]. In our study, CPP showed strong $(P<0.001)$ and dose-dependent inhibition of cotton pellet granuloma and is indicative of its potential to hasten the repair phase of inflammation. 
Analgesia is an important ancillary property of all anti-inflammory agents. Most of the antiinflammatory drugs increased the pain threshold in various animal models [31]. This is natural because many endogenous chemical mediators of inflammation play a part in generating pain impulses (for example histamine, serotonin, prostaglandins), and some other mediators such as bradykinin and cytokines are involved in the prolongation of the sensation of the pain [32].

The syndrome of writhing-lengthwise stretches of the torso accompanied (usually) by concave arching of the back-produced by acetic acid, was sensitive and a well-accepted method for the evaluation of mild analgesic nonsteroidal anti-inflammatory compounds [33-35]. The writhing test is also largely employed as an assay of visceral nociception, which represents a major clinical problem [36]. Writhing, thought to be reflexive in nature, is produced by a caudally directed wave of abdominal wall muscle constrictions and elongations, and is often followed by a characteristic hind limb extension. Acetic acid stimulates several inflammatory mediators such as cytokines and eicosanoids, which indirectly sensitizes the pain nerve endings and causes the abdominal constriction [37]. In the present study, intraperitoneal administration of acetic acid induced a severe writhing response, whereas CPP showed a mild reduction in acetic acid-induced writhing at 200 $\mathrm{mg} / \mathrm{kg}$, p.o.

The pain threshold of the inflamed edematous right hind rat paw was subjected to constant force, and examined by the Randall-Selitto assay method [38]. In the present study, CPP could show only mild reduction (20\%) in the pain latency threshold (PWT) of carrageenaninduced rat paw edema as shown in the Randall-Selitto assay (Table 1). The mild analgesic effect shown by CPP is indicative of stimulus propagation or cytokine blockage in the pain nervous fibers as the basis of the analgesic effect.

Adjuvant-induced arthritis (AIA) in rats is commonly used to evaluate compounds that might be of potential use as drugs for the treatment of rheumatoid arthritis and other chronic inflammatory conditions. Injection of Freund's adjuvant suspended in mineral oil (Freund's complete adjuvant, FCA) into rats produces an immune reaction that characteristically involves inflammatory destruction of cartilage and bone of the distal joints with concomitant swelling of surrounding tissues. FCA induced a series of cellular events leading to T-cell activation and polyarthritis [39].

AIA is a rather aggressive and monophasic form of arthritis; usually, the disease is quite severe and finally leads to complete ankylosis and permanent joint deformations. The progression of arthritis was confirmed in our study by the increase in edema (paw volume). The diseases progressed until day-12 and then became quiescent. CPP halted the progression which was evident by a significant decrease shown in the paw volume (Table 3).

The inflammation associated with AIA is dependent on prostaglandin E2 (PGE2) generated by cyclooxygenases (COXs) $[40,41]$. Besides, the role of cytokines like TNF- $\alpha$ and IL-1 has also been implicated in this model [42]. In the present study, CPP treatment for 10 days reduced paw volumes of arthritic paws in rats. Therefore, the anti-inflammatory action of CPP can be attributed to prostaglandin and/or cytokine inhibition. These results are also in line with reports that the anti-inflammatory action of cinnamon bark has been attributed to polyphenolic components such as tannins [7] and procyanidines [21]. The 
inhibition of lipid peroxidation, capillary permeability and fragility, and enzymes such as phospholipase A2, cyclooxygenase, and lipoxygenase was reported as the alleged mechanism for cinnamon tannins and polyphenols [7,21]. However, the absence of the analgesic effects of CPP as indicated in the acetic acid-induced writhing model (Table 2) suggested cytokine inhibition rather than prostaglandin inhibition as the potential mechanism for the anti-inflammatory effect of CPP.

One of the most prominent and serious side effects of NSAIDs is the occurrence of gastrointestinal damage (ulcerogenicity). In the present study, for subacute treatment, CPP (200 mg/kg p.o. for 10 days) did not cause ulcers in the established AIA in rats (Figure 2). Further, cinnamon bark extract and polyphenols have been shown to possess cytokine inhibitory effects in vitro $[15,43]$. An in vitro pre-challenge with cinnamon extract is reported to suppress lipopolysaccharide (LPS)-induced cytokine expression [44]. The absence of ulcerogenicity, and mild analgesic potential with good anti-inflammatory activity, is in line with the view that CPP has disease-modifying potential. In addition, cytokine inhibition emerges as the probable mechanism for CPP which is well-supported by its cachexia-reducing effects shown in established AIA-induced polyarthritis in rats in the present study.

Cytokines are known to regulate several events in immune response including cell cooperation, proliferation, differentiation, and death. Research has also suggested that skeletal muscle protein loss is dependent upon the signaling activities of both TNF- $\alpha$ and IFN- $\gamma$, and that nuclear factor kappa $B\left(N K_{B}\right)$ activity is needed for these cytokines to induce muscle damage [45]. In chronic inflammation, an activated immune system can release a series of pro-inflammatory cytokines, including tumor necrosis factor- (TNF $\alpha$ ). RA progression is associated with an imbalance of Th1/Th2 and overproduction of antigen-specific immunoglobulin [46]. Several cytokines (TNF- $\alpha$, IL-1, IL-6, and GM-CSF) and activated $B$ cells, T-cells, and antigen-presenting cells play a crucial role in RA joint inflammation. The efficacy of anti-TNF $\alpha$ and anti-IL-1 agents in the treatment of RA patients is established $[47,48]$. In the present investigation, the effect of CPP on serum TNFa release from FCA-induced arthritic rats at a dose of $200 \mathrm{mg} / \mathrm{kg}$ was estimated. In our study, AIA rats showed a significant increase in serum TNFa levels on day 12. CPP treatment (for 10 days) showed a significant reduction in elevated TNFa levels in AIA rats on day 21 of the study (Table 3). AIA in rats is also a useful model of inflammatory cachexia that mimics the human pathophysiology in many important ways [49]. Secondary reactions in AIA are characterized by immune responses, inflammation, and severe weight Ioss (cachexia). In our study, the test compound CPP significantly protected rats from AIAinduced cachexia (Table 3). Cachexia associated with RA persists even after joint inflammation improves [50]. Further, rheumatoid cachexia leads to muscle weakness and a loss of functional capacity, and is believed to accelerate morbidity and mortality in rheumatoid arthritis [51]. Excess production of the inflammatory cytokines is known to have a definite role in the development of rheumatoid cachexia. TNFa is probably the central mediator of muscle wasting in RA, and is known to act synergistically with interleukin-1 $\beta$ to promote cachexia [51].

Cytokines elaborated by activated T-cells play a major role in the regulation of immune responses. When environmental substances (molecules or microbes) gain access to the body, these substances (termed antigens) are recognized as foreign by antigen receptors that are expressed on the surface of lymphocytes. In an attempt to further understanding 
of the role of cytokines in the mechanism of CPP, we have analyzed T-cell-derived cytokines in the spleen lymphocyte supernatant isolated from mice. The proliferation response of $\mathrm{T}$-cells to a polyclonal mitogen, ConA, in culture supernatant and their cytokine secretion profiles are well-documented [52]. These cytokines are normally produced by the body during an immune response [53]. In our study, the test compound CPP was found to inhibit cytokines (IL-2, IL-4, and IFN Y) in ConA-stimulated spleen cell culture supernatant (Table 4). IL-2 is necessary for the development of T-cell immunologic memory, one of the unique characteristics of the immune system, which depends upon the expansion of the number and function of antigen-selected T-cell clones. IL-2 is also necessary during T-cell development in the thymus for the maturation of regulatory T-cells (Tregs) [54] which results in autoimmunity. IL-4 is an important immune cytokine which regulates the function of lymphocytes and macrophages [55]. Several lines of evidence exist confirming the role of Th2 cell activation and production of cytokines such as IL-4 in RA and other autoimmune diseases [56-58]. Further, circulating IFN $y$ can be detected in patients with autoimmune diseases like RA [59]. These results suggest the inhibitory effects of CPP on lymphocyte proliferation and the reduction of autoimmunity as a probable basis for the disease-modifying anti-rheumatic effects of CPP in RA.

Taken together, our results indicated cytokine inhibition as the probable mechanism of action of CPP against rheumatoid arthritis. Further, the lack of analgesic action and ulcerogenicity pointed to CPP as a disease-modifying anti-rheumatic drug (DMARD). DMARDs suppress the rheumatoid process and bring about a remission, but do not have non-specific anti-inflammatory or analgesic action. CPP can provide added advantages such as lack of gastric and cardiovascular side effects. Cinnamon bark extract had been reported to inhibit gastric secretions [11] and irradiate $H$. pylori, a bacteria known to exacerbate gastric acidity and ulcers $[60,61]$. Cinnamon bark was also expected to have protective effects on the cardiovascular system due to its potent antioxidant capacity [62-66].

In conclusion, CPP showed good ameliorative effects in animal models of inflammation and rheumatoid arthritis and can be explored as a DMARD.

\section{Experimental}

\section{Animals}

Male Wistar rats (130-200 g) or Swiss albino mice (20-25 g) were obtained from the National Toxicology Centre, Pune, India. The animals were housed in polypropylene cages at a temperature of $24 \pm 1{ }^{\circ} \mathrm{C}$ in $12 \mathrm{~h}: 12 \mathrm{~h}$ dark-light cycle, with free access to standard pellet feed (Chakan Oil Mill, India) and filtered water. All experiments were carried out between 08:00 $\mathrm{h}$ and 17:00 $\mathrm{h}$ in a quiet laboratory at an ambient temperature. The research protocol (No: CPCSEA/48/08) was approved by the Institutional Animal Ethics Committee (IAEC) and as per Indian norms laid down by the Committee for the Purpose of Control and Supervision of Experimental Animals (CPCSEA), New Delhi.

\section{Chemicals}

For the in vivo studies, carrageenan and FCA (Sigma-Aldrich, St.Louis MO, USA), acetic acid (Pure Chem. Limited Ltd, Pune, India), carboxymethylcellulose (Qualigens, Mumbai, India), anaesthetic ether (Batch No. 30, TKM Pharma, Hyderabad), and the BD-OptEIA kit 
for TNF a estimation (BD Pharmingen, U.S.A) were purchased from the respective vendors. All other chemicals used were of analytical grade.

For the in vitro studies, fetal calf serum (FCS) and culture media were purchased from GIBCO BRL (Grand Islan, NY, USA). RPMI1640 (Sigma-Aldrich, St.Louis MO, USA) and Concanavalin A (ConA, Calbiochem, USA) were purchased from the respective vendors. Starch, ethanol, and all other chemicals were purchased from reputed local manufacturers. All plasticwares that were used for the in vitro studies were purchased either from Nalgene Nunc (Naperville, IL, USA) or Falcon (Becton Dickinson Labware, USA).

\section{Extraction and characterization of CPP from Cinnamon bark}

Cinnamon bark (1000 g) pieces were dried and pulverized to make powder (16 mesh). The powder was extracted with $6 \mathrm{~L}$ of a $95 \%$ ethanol-water mixture over a period of $10 \mathrm{~h}$ with the help of an extractor having a perforated bottom sieve of the 200 mesh size. The bottom eluent was recycled repeatedly. The eluent was collected and concentrated at low temperature to get a paste. The paste was dissolved in $2000 \mathrm{ml}$ of distilled water and the $\mathrm{pH}$ was adjusted to 3 with phosphoric acid and insolubles were filtered. The clear filtrate was passed through a layer of activated neutral alumina column (comprising a dry charge of $400 \mathrm{ml}$ of alumina). The adsorbed material on the column was eluted with ethyl alcohol, and concentrated to get powder of CPP (also known as IND02) (Yield: $28 \mathrm{~g}$ ). The obtained compound, CPP, was charactrized by HPLC and the total phenolic content was determined.

\section{Determination of Total Phenolic Content (TPC) of CPP}

Total phenolic content was determined with the Folin-Ciocalteu reagent according to a procedure described by Singleton and Rossi [22]. An aliquot of $1 \mathrm{ml}$ of the extract solution in methanol was mixed with $1 \mathrm{ml}$ of the Folin-Ciocalteu reagent (previously diluted with water $1: 1 \mathrm{v} / \mathrm{v}), 3 \mathrm{ml}$ of saturated sodium carbonate $\left(\mathrm{Na}_{2} \mathrm{CO}_{3}\right)$ solution (about $75 \mathrm{~g} / \mathrm{l}$ ), and $4 \mathrm{ml}$ of water. The mixture was allowed to stand at room temperature for $25 \mathrm{~min}$ and was then centrifuged at $5000 \mathrm{rpm}$ for $10 \mathrm{~min}$. Absorbance of the supernatant was measured at $755 \mathrm{~nm}$ using a spectrophotometer (Shimadzu). Gallic acid was used as a reference standard, and the results were expressed as milligram gallic acid equivalent (mg GAE)/g dry weight of CPP.

\section{Anti-inflammatory activity against carrageenan-induced rat paw edema}

Anti-inflammatory activity was evaluated on the basis of the inhibition of the carrageenaninduced hind paw edema $[67,68]$. Each rat in the experimental group (six rats each) was treated orally with 50,100, and $200 \mathrm{mg} / \mathrm{kg}$ body weight of CPP, $1 \mathrm{~h}$ before subplanter injection of the edematogenic agent, carrageenan $(0.1 \mathrm{ml}$ of a $1 \%$ suspension prepared in $0.9 \% \mathrm{NaCl}$ ) to the left hind paw of rats with a 26 gauge needle. One group of rats was treated orally with $10 \mathrm{mg} / \mathrm{kg}$ body weight of celecoxib as a standard drug. The separate vehicle control group was also maintained. Paw volume was measured immediately after the carrageenan injection (time 0 ) and at 1, 2, 3, and $24 \mathrm{~h}$ using a plethysmometer (Model 7150, Ugo Basile, Italy). The mean difference in paw volume ( $\mathrm{ml}$ ) was calculated with baseline $(0 \mathrm{~h})$ values for each rat. Percent (\%) inhibition of paw volume was calculated with a reported formula [69] from the mean difference in mean paw volume ( $\mathrm{ml}$.) in treated $(\mathrm{Vt})$ and control $(\mathrm{Vc})$ groups according to the equation: \% inhibition $=(\mathrm{Vt} / \mathrm{Vc})^{\star} 100$. 


\section{Analgesic activity in the Randall-Selitto assay against carrageenan-induced rat paw edema}

The pain stimulus of each rat was measured at the 3rd $\mathrm{h}$ after the carageenan-injected paw with the help of the Randall-Selitto analgesymeter (Ugo basile Model 7200) by the method reported earlier [38]. The apparatus was set up to apply a force of 0-500 $\mathrm{g}$ increasing from zero. The paw withdrawal threshold (PWT) was taken at the point at which the rat started to react (vocalized or struggled). The rats that did not attempt to remove their paws or vocalize before the $5000 \mathrm{~g}$ point (cut-off pressure) were discarded. Paw withdrawal threshold (PWT) was considered as a measure of pain latency. The percent increase in PWT was calculated as compared with the PWT of the vehicle control rats.

\section{Anti-inflammatory activity against cotton pellet granuloma}

Subcutaneous implantation of pellets of compressed cotton provokes foreign body granuloma [70]. Male Wistar rats (175 to $200 \mathrm{~g}$ ) were divided randomly in six groups with six rats in each group. The rats were fasted for $6 \mathrm{~h}$ before oral administration of the test compounds. Group 1 was the control group, Group 2 was the vehicle (distilled water)treated; group 3 was celecoxib-treated (10 mg/kg p.o.) and Groups 4, 5, and 6 were CPP $(50,100$, and $200 \mathrm{mg} / \mathrm{kg})$-treated groups, respectively. Cotton rolls were cut and made into pellets weighing $20 \mathrm{mg}$ each and sterilized in an autoclave at $100{ }^{\circ} \mathrm{C}$ for $30 \mathrm{~min}$. Four individual pellets were inserted in each ether-anesthetized animal by making small subcutaneous incisions in both axillae and groin regions. The incisions were sutured by sterile catgut. After recovery from anesthesia, the animals were placed in individual cages and treated orally with test drugs for seven days starting from the day of cotton pellet implantation. The animals were anaesthetized again on the 8th day and cotton pellets were removed surgically, freed from extraneous tissue, incubated at $37{ }^{\circ} \mathrm{C}$ for $24 \mathrm{~h}$, and dried at $55^{\circ} \mathrm{C}$ to constant weight. The weight of the cotton pellet before implantation was subtracted from the weight of the dried dissected pellets. Thus any increment in the dry weight of the pellets was taken as a measure for granuloma formation. The mean weight was calculated for pellets from the group of rats receiving drugs and compared with the mean values for the control.

\section{Analgesic activity against acetic acid-induced writhing in mice}

Male Swiss albino mice (20-25 gm) were divided into the following groups containing six animals in each group. Rats form Group I were administered orally with the vehicle (distilled water) and called the vehicle control. Rats from Group II were administered with celecoxib (10 mg/kg, p.o.). To rats of Group III, IV, and V were administered orally with CPP at a dose of 50, 100, and $200 \mathrm{mg} / \mathrm{kg}$. After $60 \mathrm{~min}$, all rats were administered with an intraperitoneal injection of acetic acid (10 ml/kg, 0.6\%). After $20 \mathrm{~min}$, acetic acid induced the writhing response (the abdominal min according to the procedures described [71]). The percent analgesia was calculated from the mean number of writhes in the vehicle control group $(\mathrm{Wv})$ and that of the treatment group $(\mathrm{Wt})$ as per formula: \% analgesia = $100 *[(\mathrm{Wv}-\mathrm{Wt}) / \mathrm{Wv}]$.

\section{Antiarthritic Activity of CPP against adjuvant-induced established polyarthritis (AIA)}

Induction of arthritis was performed according to the earlier described method [72] as modified for therapeutic schedule. AIA was induced in 6 to 8 week-old rats by a single intradermal injection of $0.1 \mathrm{ml}$ Freund's complete adjuvant (FCA) into the footpad of the 
right hind paw. FCA contains $0.6 \mathrm{mg}$ heat-inactivated Mycobacterium tuberculosis, H37Ra (Difco Laboratory, Detroit, MI, USA) emulsified in a sterile mixture of paraffin oil, saline, and Tween 80. Arthritis was allowed to develop for the next 12 days. On day 12, animals were randomly assigned to one of the following treatment groups: Group 1: adjuvant induced arthritis controls (AIA controls), Group 2: arthritic rats treated with celecoxib (10 $\mathrm{mg} / \mathrm{kg} /$ day), and Group 3 to 5: arthritic rats treated CPP (50, 100, and $200 \mathrm{mg} / \mathrm{kg} /$ day), respectively. These groups of rats were orally treated once daily with the following treatment: Group 1: vehicle (distilled water), Group 2: celecoxib (10 mg/kg, p.o.), and Group 3 to 5: CPP $(50,100$, or $200 \mathrm{mg} / \mathrm{kg})$ from day 12 to day 21 by oral feeding needle.

The body weights of rats were recorded at the baseline (day 0), and day12 and day 21 of the study. The difference in body weight was calculated relative to that at day 0 , allowing monitoring of the decrease in body weight gain associated with arthritis [73]. Swelling of hind paws was monitored by using a plethysmometer (UGO Basile Italy) at day 0 and 12 and 21 days after the FCA injection [74].

On day 21, rats were sacrificed and ulcerogenicity was investigated on stomach tissue samples. The stomach was dissected out, sectioned along the greater curvature, washed with saline, and the glandular portion was examined macroscopically for the number and size of mucosal lesions. The stomach pieces were placed in $10 \%$ buffered formaldehyde solution (Merck) and embedded in paraffin pastilles (Merck). Serial sections of $5 \mathrm{~mm}$ were cut and stained with Hemotaoxylin and Eosin (H\&E) (Merck). Mounting of the specimen was done by using Distrene Phthalate Xylene (D.P.X.) and examined under microscope for photomicrographic analysis [75].

\section{Serum TNFa measurement in AIA rats}

The blood samples were collected on day 0 , day 13, and day 21 of post-FCA inoculation. Serum was separated and stored at $-20^{\circ} \mathrm{C}$ until the assay. Serum TNF- $\alpha$ was estimated by the BD-OptEIA kit (BD Pharmingen, U.S.A.) using the manufacturer's protocol. Briefly, $50 \mu \mathrm{l}$ of ELISA diluent was added to each well followed by the TNF- $\alpha$ standards and samples were incubated at room temperature for $2 \mathrm{~h}$. After thorough washing, $100 \mu \mathrm{l}$ of the detection antibody (biotinylated anti-rat monoclonal TNF- $\alpha$ antibody) was added to each well and incubated for $1 \mathrm{~h}$ at room temperature. After thorough washing, $100 \mu \mathrm{l}$ of avidinhorseradish peroxidase conjugate was added to each well and incubated for 30 min at room temperature. After incubation, $100 \mu \mathrm{l}$ of the substrate reagent (3,3',5,5'-tetramethylbenzidine, TMB) was added. The reaction was stopped using $1 \mathrm{~N} \mathrm{H} 2 \mathrm{SO} 4$ and the plates were read at $450 \mathrm{~nm}$ within 30 min of stopping the reaction. All results were converted to $\mathrm{pg} / \mathrm{ml}$ using the standard curve on linear-log graph paper as suggested by the protocol [76].

\section{IL2, IL4, and IFNY concentration measurement in ConA-stimulated lymphocytes in vitro}

Three male Swiss albino mice (20-25 g) were sacrificed by cervical dislocation. The mice were dissected and spleens were removed. The spleens were then dried on a paper and used for the isolation of lymphocytes. Spleen cells were obtained by squeezing the spleen through a nylon mesh in a petriplate containing Roswell Park Memorial Institute (RPMI) medium. The hypotonic shock was given to RBCs by hypotonic $\mathrm{NH} 4 \mathrm{Cl}$ solution. Lymphocytes were washed three times using ice-cold RPMI medium containing $10 \%$ fetal 
calf serum (FCS) conditioned media. All the cells were harvested in test tubes, centrifuged at $5000 \mathrm{rpm}$ for 5-7 times, and resuspended in $5 \mathrm{ml}$ medium. Then $25 \mu \mathrm{l}$ of the cell suspension and $475 \mu \mathrm{l}$ of methylene blue was mixed and cells were counted with a hemocytometer. Spleen cells were cultured with ConA and the culture supernatants were collected 72 h. after stimulation. The supernatants were used for IL-2, IL-4, and IFNy estimation by the enzyme-linked immunosorbent assay (ELISA) kit (Pharmingen, San Jose, California, USA) as per manufacturer's instructions [77].

Two million lymphocytes were placed in each well of a 24-well culture plate. Group distribution and incubation of cells were as follows: 1 . Untreated cells served as a control, 2. ConA $(10 \mu \mathrm{g} / \mathrm{ml})$-stimulated lymphocytes served as a positive control group, 3 . ConA(40 $\mu \mathrm{l})$-stimulated lymphocytes in the presence of CPP $(100 \mu \mathrm{l}, 0.4 \%$ i.e. $40 \mu \mathrm{g} / 100 \mu \mathrm{l})$. The final 24-well culture plate $(1 \mathrm{ml})$ concentration of three different groups was as follows: (1) Control Cells $(220 \mu \mathrm{l})+$ FCS $(120 \mu \mathrm{l})+\mathrm{RPMI}(660 \mu \mathrm{l}),(2)$ ConA-treated cells $(220 \mu \mathrm{l})+$ FCS $(120 \mu \mathrm{l})+$ ConA $(40 \mu \mathrm{l})+\mathrm{RPMI}(620 \mu \mathrm{l})$, and (3) CPP-treated cells $(220 \mu \mathrm{l})+\mathrm{FCS}$ $(120 \mu \mathrm{l})+$ ConA $(40 \mu \mathrm{l})+\mathrm{RPMI}(520 \mu \mathrm{l})+\mathrm{IND} 02(100 \mu \mathrm{l})$. Lymphocytes were cultured for $72 \mathrm{~h}$ at $37^{\circ} \mathrm{C}$ in $2 \mathrm{ml}$ culture medium in a 95\% air/5\% CO2 atmosphere in a CO2 incubator until assaying.

Levels of IL-2, IL4, and IFNy were estimated by commercially available ELISA kits (BD-Opt EIA kits, BD Pharmingen, U.S.A.) using the manufacturer's protocols. Samples were acidified with $1 \mathrm{~N} \mathrm{HCl}$ and incubated at room temperature for $15 \mathrm{~min}$, neutralized with $1 \mathrm{~N}$ $\mathrm{NaOH}$, and used for the sandwich ELISA procedure. Ninety-six-well high-binding ELISA plates (BD Falcon ELISA plates) were coated with $100 \mu$ l of capture antibody (either with anti-rat IL-2 or IL-4 or IFNy) and maintained overnight at $4{ }^{\circ} \mathrm{C}$. The plate was brought to room temperature the next day and was blocked by $200 \mu \mathrm{l}$ of assay diluent and incubated for $2 \mathrm{~h}$. After washing, $100 \mu \mathrm{l}$ of standards (provided with the kit) and samples were added to each well and incubated for 1 hour. Then $100 \mu \mathrm{l}$ of biotinylated antimouse IL-1 $\beta$ was used as the detection antibody. After thorough washing, $100 \mu \mathrm{l}$ of avidin-horseradiish peroxidase conjugate was added to each well and incubated for $30 \mathrm{~min}$ at room temperature. After incubation, $100 \mu \mathrm{l}$ of the substrate reagent (3,3,5,5'- tetramethylbenzidine, TMB) was added. The reaction was stopped with $1 \mathrm{~N} \mathrm{H} 2 \mathrm{SO} 4$ and the absorbance was read at $450 \mathrm{~nm}$ in an ELISA plate reader (Biotek Instruments Inc, USA). All the results were converted to $\mathrm{pg} / \mathrm{ml}$ using the standard curve on linear-log graph paper as suggested by the protocol.

\section{Statistical analysis}

The carrageenan-induced rat paw edema experiment (paw volume), FCA-induced established polyarthritis, AIA model (body weight, paw volume, and TNFa levels), and ConA-stimulated lymphocytes in vitro experiment (IL2, IL-4 and IFN-ylevels) were analysed by separate two-way ANOVA followed by Bonferroni post-tests. The data obtained in the cotton pellet granuloma experiment (mean weight of cotton pellets) and acetic acid-induced writhing model in rats (mean number of writhes) were analysed by separate one-way ANOVA followed by Dunnett's t-test. $P<0.05$ was considered significant. 


\section{Acknowledgement}

The authors would like acknowledge Dr. K. R. Mahadik, Principal, Poona College of Pharmacy, Bharati Vidyapeeth Deemed University and Pune for providing the necessary facilities and Sunil Bhaskaran, MD, Indus Biotech Private Limited, Pune India for research support.

\section{Authors' Statements}

\section{Competing Interests}

The authors declare no conflict of interest. The research support of Indus Biotech Private Limited did not have a role in the analysis and interpretation of the data.

\section{Informed Consent, Ethical Approvals, Animal Rights}

The research protocol was approved by the Institutional Animal Ethics Committee (IAEC) of the Poona College of Pharmacy, Pune and as per Indian norms laid down by the Committee for the Purpose of Control and Supervision of Experimental Animals (CPCSEA), New Delhi.

\section{References}

[1] Firestein GS.

VIP: a very important protein in arthritis.

Nat Med. 2001; 7: 537-538.

http://dx.doi.org/10.1038/87859

[2] Warrier PK, Ramankutty C, Nambiar VPK, Nair RV.

Indian medicinal plants : a compendium of 500 species.

Madras: Orient Longman, 1993.

[3] Kirtikar KR, Basu B, Blatter E.

Indian medicinal plants.

Dehra Dun: Bishen Singh Mahendra Pal Singh, 1975.

[4] Khory RN, Katrak NN.

Materia medica of India and their therapeutics.

Delhi: Neeraj Publishing House, 1903; 809 p.

[5] Ambasto SP, ed.

The useful plants of India.

New Delhi: Publications and Information Directorate, Council of Scientific and Industrial Research; 1986.

[6] Asolkar LV, Chopra RN, Kakkar KK, Chakre OJ; eds.

Second supplement to Glossary of Indian medicinal plants with active principles.

Part 1, (A-K) (1965-1981).

New Delhi: Publications \& Information Directorate, CSIR; 1992.

[7] Newall CA, Anderson LA, Phillipson JD.

Herbal medicines : a guide for health-care professionals.

London: Pharmaceutical Press, 1996.

[8] Kubo M, Ma S, Wu J, Matsuda $\mathrm{H}$.

Anti-inflammatory activities of $70 \%$ methanolic extract from Cinnamomi Cortex.

Biol Pharm Bull. 1996; 19: 1041-1045.

http://dx.doi.org/10.1248/bpb.19.1041 
[9] Mitra SK, Sundaram R, Venkataranganna MV, Gopumadhavan S, Prakash NS, Jayaram HD, Sarma DN.

Anti-inflammatory, antioxidant and antimicrobial activity of Ophthacare brand, an herbal eye drops.

Phytomedicine. 2000; 7: 123-127.

http://dx.doi.org/10.1016/S0944-7113(00)80084-7

[10] Atta AH, Alkofahi A.

Anti-nociceptive and anti-inflammatory effects of some Jordanian medicinal plant extracts.

J Ethnopharmacol. 1998; 60: 117-124.

http://dx.doi.org/10.1016/S0378-8741(97)00137-2

[11] Ravindran PN, Nirmal Babu K, Shylaja M; eds.

Cinnamon and cassia : the genus Cinnamomum.

Boca Raton: CRC Press; 2004.

[12] Chang H-M, But PP-H; eds.

Pharmacology and applications of Chinese materia medica.

Singapore: World Scientific; 1986.

[13] Lee BJ, Kim YJ, Cho DH, Sohn NW, Kang H.

Immunomodulatory effect of water extract of cinnamon on anti-CD3-induced cytokine responses and p38, JNK, ERK1/2, and STAT4 activation.

Immunopharmacol Immunotoxicol. 2011; 33: 714-722.

http://dx.doi.org/10.3109/08923973.2011.564185

[14] Tang W, Eisenbrand G.

Chinese drugs of plant origin : chemistry, pharmacology, and use in traditional and modern medicine. Berlin: Springer-Verlag, 1992.

[15] Cao H, Urban JF, Jr., Anderson RA.

Cinnamon polyphenol extract affects immune responses by regulating anti- and proinflammatory and glucose transporter gene expression in mouse macrophages.

J Nutr. 2008; 138: 833-840.

http://www.ncbi.nlm.nih.gov/pubmed/18424588

[16] Lazarus SA, Adamson GE, Hammerstone JF, Schmitz HH.

High-performance liquid Chromatography/Mass spectrometry analysis of proanthocyanidins in foods and beverages.

J Agric Food Chem. 1999; 47: 3693-3701.

http://dx.doi.org/10.1021/jf9813642

[17] Garella S, Matarese RA.

Renal effects of prostaglandins and clinical adverse effects of nonsteroidal anti-inflammatory agents. Medicine (Baltimore). 1984; 63: 165.

http://dx.doi.org/10.1097/00005792-198405000-00003

[18] Pennings EJ, Verkes RJ, de Koning J, Bommele JJ, Jansen GS, Vermeij P.

Tranylcypromine intoxication with malignant hyperthermia, delirium, and thrombocytopenia.

J Clin Psychopharmacol. 1997; 17: 430-432.

http://dx.doi.org/10.1097/00004714-199710000-00020

[19] Prasit P, Wang Z, Brideau C, Chan CC, Charleson S, Cromlish W, Ethier D, Evans J,

Ford-Hutchinson A, Gauthier J.

The discovery of rofecoxib,[MK 966, VIOXX®, 4-(4'-methylsulfonylphenyl)-3-phenyl-2(5H)-furanone], an orally active cyclooxygenase-2 inhibitor.

Bioorg Med Chem Lett. 1999; 9: 1773-1778.

http://dx.doi.org/10.1016/S0960-894X(99)00288-7 
[20] Anderson RA, Broadhurst CL, Polansky MM, Schmidt WF, Khan A, Flanagan VP, Schoene NW, Graves DJ.

Isolation and characterization of polyphenol type-A polymers from cinnamon with insulin-like biological activity.

J Agric Food Chem. 2004; 52: 65-70.

http://dx.doi.org/10.1021/jf034916b

[21] Fine AM.

Oligomeric proanthocyanidin complexes: history, structure, and phytopharmaceutical applications.

Altern Med Rev. 2000; 5: 144-151.

http://www.ncbi.nlm.nih.gov/pubmed/10767669

[22] Singleton V, Rossi Jr J.

Colorimetry of total phenolics with phosphomolybdic-phosphotungstic acid reagents.

Am J Enology Viticult. 1965; 16: 144.

[23] Spector WG, Willoughby DA; eds.

The pharmacology of inflammation.

London: English Universities; 1968.

[24] Sharma JN.

Involvement of the kinin-forming system in the physiopathology of rheumatoid inflammation.

Agents Actions Suppl. 1992; 38 (Pt 3): 343-361.

http://www.ncbi.nlm.nih.gov/pubmed/1334358

[25] Scott DT, Lam FY, Ferrell WR.

Acute joint inflammation--mechanisms and mediators.

Gen Pharmacol. 1994; 25: 1285-1296.

http://dx.doi.org/10.1016/0306-3623(94)90151-1

[26] Tanaka S, Sohen S, Fukuda K.

A role for histamine receptors in rheumatoid arthritis.

Semin Arthritis Rheum. 1997; 26: 824-833.

http://dx.doi.org/10.1016/S0049-0172(97)80026-1

[27] Lombardino JG.

Nonsteroidal antiinflammatory drugs.

New York; Chichester: Wiley, 1985; 442.

[28] Tang L, Jennings TA, Eaton JW.

Mast cells mediate acute inflammatory responses to implanted biomaterials.

Proc Natl Acad Sci U S A. 1998; 95: 8841-8846.

http://dx.doi.org/10.1073/pnas.95.15.8841

[29] Koganov M, Dueva O, Tsorin B.

Activities of plant-derived phenols in a fibroblast cell culture model.

J Nat Prod. 1999; 62: 481-483.

http://dx.doi.org/10.1021/np9801559

[30] Swingle KT.

Evaluation of anti-inflammatory activity.

In: Scherrer RA, Whitehouse MW; eds.

Antiinflammatory agents; chemistry and pharmacology. 34 .

New York: Academic Press, 1974; 122.

[31] Scherrer RA, Whitehouse MW; eds.

Antiinflammatory agents : chemistry and pharmacology.

New York; London: Academic Press; 1974.

[32] Besson JM.

[The complexity of physiopharmacologic aspects of pain].

Drugs. 1997; 53 (Suppl 2): 1-9.

http://www.ncbi.nlm.nih.gov/pubmed/9190319 
[33] Ferreira S, Vane J.

New aspects of the mode of action of nonsteroid anti-inflammatory drugs.

Annu Rev Pharmacol. 1974; 14: 57-73.

http://dx.doi.org/10.1146/annurev.pa.14.040174.000421

[34] Van der Wende C, Margolin S; eds.

Analgesic tests based upon experimentally induced acute abdominal pain in rats.

Fed Proc. 1956; 15: 494.

[35] Siegmund E, Cadmus R, Lu G.

A method for evaluating both non-narcotic and narcotic analgesics.

Proc Soc Exp Biol Med. 1957; 95: 729-731.

http://www.ncbi.nlm.nih.gov/pubmed/13465785

[36] McMahon S.

Are there fundamental differences in the peripheral mechanisms of visceral and somatic pain?

Behav Brain Sci. 1997; 20: 381-391.

http://dx.doi.org/10.1017/S0140525X97231481

[37] Martinez V, Thakur S, Mogil JS, Tache Y, Mayer EA.

Differential effects of chemical and mechanical colonic irritation on behavioral pain response to intraperitoneal acetic acid in mice.

Pain. 1999; 81: 179-186.

http://dx.doi.org/10.1016/S0304-3959(99)00008-1

[38] Randall LO, Selitto JJ.

A method for measurement of analgesic activity on inflamed tissue.

Arch Int Pharmacodyn Ther. 1957; 111: 409-419.

http://www.ncbi.nlm.nih.gov/pubmed/13471093

[39] Billingham MEJ.

Models of arthritis and the search for anti-arthritic drugs.

In: Orme M, ed.

Anti-rheumatic drugs.

New York: Pergamon, 1990; 1-47.

[40] Anderson GD, Hauser SD, McGarity KL, Bremer ME, Isakson PC, Gregory SA.

Selective inhibition of cyclooxygenase (COX)-2 reverses inflammation and expression of COX-2 and interleukin 6 in rat adjuvant arthritis.

J Clin Invest. 1996; 97: 2672-2679.

http://dx.doi.org/10.1172/JCl118717

[41] Billingham $M$.

Models of arthritis and the search for anti-arthritic drugs.

Pharmacol Ther. 1983; 21: 389-428.

http://dx.doi.org/10.1016/0163-7258(83)90062-1

[42] He YP, Li ZY, Jiang XD, Feng W, Xu Y, Xiong P.

[Effects of TNF-alpha receptor blocking peptide on adjuvant arthritis in rats].

Yao Xue Xue Bao. 2003; 38: 889-892.

http://www.ncbi.nlm.nih.gov/pubmed/15040077

[43] Qin B, Dawson H, Polansky MM, Anderson RA.

Cinnamon extract attenuates TNF-alpha-induced intestinal lipoprotein ApoB48 overproduction by regulating inflammatory, insulin, and lipoprotein pathways in enterocytes.

Horm Metab Res. 2009; 41: 516-522.

http://dx.doi.org/10.1055/s-0029-1202813

[44] Kanuri G, Weber S, Volynets V, Spruss A, Bischoff SC, Bergheim I.

Cinnamon extract protects against acute alcohol-induced liver steatosis in mice.

J Nutr. 2009; 139: 482-487.

http://dx.doi.org/10.3945/jn.108.100495 
[45] Guttridge DC, Mayo MW, Madrid LV, Wang CY, Baldwin AS, Jr.

NF-kappaB-induced loss of MyoD messenger RNA: possible role in muscle decay and cachexia. Science. 2000; 289: 2363-2366.

http://dx.doi.org/10.1126/science.289.5488.2363

[46] Panayi G.

T-cell-dependent pathways in rheumatoid arthritis.

Curr Opin Rheumatol. 1997; 9: 236.

http://dx.doi.org/10.1097/00002281-199705000-00010

[47] Feldmann M, Maini RN.

Discovery of TNF- $\alpha$ as a therapeutic target in rheumatoid arthritis: preclinical and clinical studies.

Joint Bone Spine. 2002; 69: 12-8.

http://dx.doi.org/10.1016/S1297-319X(01)00335-9

[48] Lipsky PE, van der Heijde DM, St Clair EW, Furst DE, Breedveld FC, Kalden JR, Smolen JS, Weisman M, Emery P, Feldmann M, Harriman GR, Maini RN; Anti-Tumor Necrosis Factor Trial in Rheumatoid Arthritis with Concomitant Therapy Study Group.

Infliximab and methotrexate in the treatment of rheumatoid arthritis. Anti-Tumor Necrosis Factor Trial in Rheumatoid Arthritis with Concomitant Therapy Study Group.

N Engl J Med. 2000; 343: 1594-602.

http://dx.doi.org/10.1056/NEJM200011303432202

[49] Roubenoff R, Freeman L, Smith D, Abad L, Dinarello C, Kehayias J.

Adjuvant arthritis as a model of inflammatory cachexia.

Arthritis Rheum. 1997; 40: 534-539.

http://dx.doi.org/10.1002/art.1780400320

[50] Roubenoff $\mathrm{R}$.

Rheumatoid cachexia: a complication of rheumatoid arthritis moves into the 21st century.

Arthritis Res Ther. 2009; 11: 108.

http://dx.doi.org/10.1186/ar2658

[51] Walsmith J, Roubenoff R.

Cachexia in rheumatoid arthritis.

Int J Cardiol. 2002; 85: 89-99.

http://www.ncbi.nlm.nih.gov/pubmed/12163213

[52] Erhardt A, Biburger M, Papadopoulos T, Tiegs G.

IL-10, regulatory T cells, and Kupffer cells mediate tolerance in concanavalin A-induced liver injury in mice.

Hepatology. 2007; 45: 475-485.

http://dx.doi.org/10.1002/hep.21498

[53] Cantrell DA, Smith KA.

The interleukin-2 T-cell system: a new cell growth model.

Science. 1984; 224: 1312-1316.

http://dx.doi.org/10.1126/science.6427923

[54] Sakaguchi S, Sakaguchi N, Asano M, Itoh M, Toda M.

Immunologic self-tolerance maintained by activated T cells expressing IL-2 receptor alpha-chains (CD25). Breakdown of a single mechanism of self-tolerance causes various autoimmune diseases. J Immunol. 1995; 155: 1151-1164.

http://www.ncbi.nlm.nih.gov/pubmed/7636184

[55] Watanabe $\mathrm{Y}$, Lee S, Allison AC.

Control of the expression of a class II major histocompatibility gene (HLA-DR) in various human cell types: down-regulation by IL-1 but not by IL-6, prostaglandin E2, or glucocorticoids.

Scand J Immunol. 1990; 32: 601-609.

http://dx.doi.org/10.1111/j.1365-3083.1990.tb03202.x 
[56] Simon AK, Seipelt E, Sieper J.

Divergent T-cell cytokine patterns in inflammatory arthritis.

Proc Natl Acad Sci U S A. 1994; 91: 8562-8566.

http://dx.doi.org/10.1073/pnas.91.18.8562

[57] Romagnani S.

Lymphokine production by human T cells in disease states.

Annu Rev Immunol. 1994; 12: 227-57.

http://dx.doi.org/10.1146/annurev.iy.12.040194.001303

[58] Nicholson LB, Kuchroo VK.

Manipulation of the Th1/Th2 balance in autoimmune disease.

Curr Opin Immunol. 1996; 8: 837-842.

http://dx.doi.org/10.1016/S0952-7915(96)80013-6

[59] DeGre M, Mellbye OJ, Clarke-Jenssen O.

Immune interferon in serum and synovial fluid in rheumatoid arthritis and related disorders.

Ann Rheum Dis. 1983; 42: 672-676.

http://dx.doi.org/10.1136/ard.42.6.672

[60] Tabak M, Armon R, Neeman I.

Cinnamon extracts' inhibitory effect on Helicobacter pylori.

J Ethnopharmacol. 1999; 67: 269-277.

http://dx.doi.org/10.1016/S0378-8741(99)00054-9

[61] Nir Y, Potasman I, Stermer E, Tabak M, Neeman I.

Controlled trial of the effect of cinnamon extract on Helicobacter pylori.

Helicobacter. 2000; 5: 94-97.

http://dx.doi.org/10.1046/j.1523-5378.2000.00014.x

[62] Hasani-Ranjbar S, Larijani B, Abdollahi M.

A systematic review of the potential herbal sources of future drugs effective in oxidant-related diseases.

Inflamm Allergy Drug Targets. 2009; 8: 2-10.

http://dx.doi.org/10.2174/187152809787582561

[63] Dhuley JN.

Anti-oxidant effects of cinnamon (Cinnamomum verum) bark and greater cardamom (Amomum

subulatum) seeds in rats fed high fat diet.

Indian J Exp Biol. 1999; 37: 238-242.

http://www.ncbi.nlm.nih.gov/pubmed/10641152

[64] Lee JS, Jeon SM, Park EM, Huh TL, Kwon OS, Lee MK, Choi MS.

Cinnamate supplementation enhances hepatic lipid metabolism and antioxidant defense systems in high cholesterol-fed rats.

J Med Food. 2003; 6: 183-191.

http://dx.doi.org/10.1089/10966200360716599

[65] Lin CC, Wu SJ, Chang CH, Ng LT.

Antioxidant activity of Cinnamomum cassia.

Phytother Res. 2003; 17: 726-730.

http://dx.doi.org/10.1002/ptr.1190

[66] Panickar KS, Polansky MM, Anderson RA.

Cinnamon polyphenols attenuate cell swelling and mitochondrial dysfunction following oxygen-glucose deprivation in glial cells.

Exp Neurol. 2009; 216: 420-427.

http://dx.doi.org/10.1016/j.expneurol.2008.12.024

[67] Winter CA, Risley EA, Nuss WG.

Carrageenin-induced edema in hind paw of the rats as an assay for anti-inflammatory drugs.

Proc Soc Exp Biol Med. 1962; 111: 544-547.

http://www.ncbi.nlm.nih.gov/pubmed/14001233 
[68] Roy DK, Kumar KT, Karmakar S, Pal S, Samanta SK, Adhikari D, Sen T.

Pharmacological studies on Indian black tea (leaf variety) in acute and chronic inflammatory conditions.

Phytother Res. 2008; 22: 814-819.

http://dx.doi.org/10.1002/ptr.2375

[69] Nargund LV, Hariprasad V, Reedy GR.

Synthesis and anti-inflammatory activity of fluorinated phenyl styryl ketones and N-phenyl-5substituted aryl-3-p-(fluorophenyl) pyrazolins and pyrazoles.

J Pharm Sci. 1992; 81: 892-894.

http://dx.doi.org/10.1002/jps.2600810910

[70] Swingle KF, Shideman FE.

Phases of the inflammatory response to subcutaneous implantation of a cotton pellet and their modification by certain anti-inflammatory agents.

J Pharmacol Exp Ther. 1972; 183: 226-234.

http://www.ncbi.nlm.nih.gov/pubmed/4562620

[71] Collier HO, Dinneen LC, Johnson CA, Schneider C.

The abdominal constriction response and its suppression by analgesic drugs in the mouse.

$\mathrm{Br}$ J Pharmacol. 1968; 32: 295-310.

http://www.ncbi.nlm.nih.gov/pubmed/4230818

[72] Ward JR, Cloud RS.

Comparative effect of antirheumatic drugs on adjuvant-induced polyarthritis in rats.

J Pharmacol Exp Ther. 1966; 152: 116-121.

http://www.ncbi.nlm.nih.gov/pubmed/5937395

[73] Koufany M, Moulin D, Bianchi A, Muresan M, Sebillaud S, Netter P, Weryha G, Jouzeau JY. Anti-inflammatory effect of antidiabetic thiazolidinediones prevents bone resorption rather than cartilage changes in experimental polyarthritis.

Arthritis Res Ther. 2008; 10: R6.

http://dx.doi.org/10.1186/ar2354

[74] Hua J, Suguro S, Hirano S, Sakamoto K, Nagaoka I.

Preventive actions of a high dose of glucosamine on adjuvant arthritis in rats.

Inflamm Res. 2005; 54: 127-132.

http://dx.doi.org/10.1007/s00011-004-1333-6

[75] Balkan A, Goren Z, Urgun H, Calis U, Cakar AN, Atilla P, Uzbay T.

Evaluation of the analgesic and anti-inflammatory activities of some thiazolo[4,5-d]pyrimidines.

Arzneimittelforschung. 2002; 52: 462-467.

http://dx.doi.org/10.1055/s-0031-1299915

[76] Conway JG, Andrews RC, Beaudet B, Bickett DM, Boncek V, Brodie TA, Clark RL, Crumrine RC, Leenitzer MA, McDougald DL, Han B, Hedeen K, Lin P, Milla M, Moss M, Pink H, Rabinowitz MH, Tippin T, Scates PW, Selph J, Stimpson SA, Warner J, Becherer JD.

Inhibition of tumor necrosis factor-alpha (TNF-alpha) production and arthritis in the rat by GW3333, a dual inhibitor of TNF-alpha-converting enzyme and matrix metalloproteinases.

J Pharmacol Exp Ther. 2001; 298: 900-908.

http://www.ncbi.nlm.nih.gov/pubmed/11504783

[77] Pandey R, Shankar BS, Sharma D, Sainis KB.

Low dose radiation induced immunomodulation: effect on macrophages and CD8+ T cells.

Int J Radiat Biol. 2005; 81: 801-812.

http://dx.doi.org/10.1080/09553000500531886 